\title{
Increase Banana Production with Various Applications of Organic Fertilizers
}

\author{
I Nyoman Sunarta* and Ni Made Trigunasih
}

\author{
Staff and Lecturer of Agrotechnology Department, Faculty of Agriculture, Udayana University, Bukit Jimbaran, Bali, \\ Indonesia. \\ *Corresponding author: nangrubynyoman@yahoo.co.id
}

\begin{abstract}
Banana is a fruit that must be present in every activity of the Balinese people. Almost in every cultural and religious activity it is compulsory to present the banana fruit, even more Bali as a tourism area really need fruits including bananas. Therefore the need of bananas is highly demanded in traditional markets or supermarkets in Bali. Until now, the banana production in Bali is far below demand, therefore we still import form places outside of Bali. Banana has a high nutrient value due to nutrients found in it such as potassium and folic acid that is needed by the body. It is also a good source of calcium, phosphor, nitrogen, and vitamins such as vitamin A, vitamin C, and B complexes which helps to repair and regenerate tissues of the body. Banana plants can grow in many places, from low grounds until highlands and in various types of soil. Nevertheless for the optimal growth; fertile soil, crumbly thick, lots of humus, aeration, and a good drainage as well as enough water is all needed. By optimizing land use, banana plants are often planted as a sideline plant for plantation of coconut, cocoa, and coffee, as well as sideline plants for many other in-between plantations. The way of planting the banana is a conventional method that is commonly used by local farmers including those in the Angkah village. For growth of banana plants we must consider and ensure before planting a crumbly soil when it is solid, to make drainage, and to make levels in slopes. During plantation organic/compost fertilizers is needed as much as $15-20 \mathrm{~kg}$ for each hole for plantation. Organic fertilizers that are added influences the good production for both quantity and quality which makes the fruit tastier and has a higher nutritional value. There are some types of organic fertilizers that are used in this research that are: cow waste organic fertilizer, chicken waste organic fertilizer, pig waste organic fertilizer, goat waste organic fertilizer, and compost fertilizer with a dosage of $15 \mathrm{~kg}$ per plant. The placement of fertilizers for each places of treatment is conducted by using a Random Group Design (RGD). The total treatments are 6 and are repeated 3 times. Planting is conducted on the $7^{\text {th }}$ of July 2016 with a ground hole size of $60 \mathrm{~cm} \times 60 \mathrm{~cm}$ and a depth of $50 \mathrm{~cm}$. The seedlings that are used are decedents that are $50-65 \mathrm{~cm}$ in height. The specific aim that is wished to be achieved is the increase production of banana as sustainable food in Indonesia. The result up to the progress of this research was found that treatment with chicken waste fertilizer has given the best influence for growth of the banana plant, increased number of leaves, as well as increased height of the plants, all compared to the controlled. The increment of banana plant with chicken waste fertilizer was $63.33 \mathrm{~cm}$ for 3 months.
\end{abstract}

\section{Keywords: Banana, Nutritional Values, Production, Organic Fertilizer}

\section{INTRODUCTION}

\section{INTRODUCTION}

Banana is the most popular fruit in the community especially in Bali. Almost in every cultural and religious ceremony there must be some banana fruits, even more Bali as a tourism area needs fruits especially bananas. Until today the production of banana in Bali is far from what is needed, therefore it is imported from places outside of Bali such as the island of Java, Lombok, Sumbawa, and even from Celebes. Banana fruit has a high nutritional value because of its nutritious composition such as potassium and folic acid which is highly needed during pregnancy. It is also a good source of calcium, phosphor, nitrogen, and vitamins such as vitamin $\mathrm{A}$, vitamin $\mathrm{C}$, and $\mathrm{B}$ complexes which helps to repair and regenerate tissues of the body. Due to its good nutritional values, therefore banana is a very good healthy food as a crop fulfillment.

Banana plants can grow in many places, from low grounds until highlands and in various types of soil. Nevertheless for the optimal growth; fertile soil, crumbly thick, lots of humus, aeration, and a good drainage as well as enough water is all needed. By optimizing land use, banana plants are often planted as a sideline plant for plantation of coconut, cocoa, and coffee, as well as sideline plants for many other in-between plantations. The way of planting the banana is a conventional method that is commonly used by local farmers including those in the Angkah village. 
A good media for plantation will be very helpful for the growth of the bananas. As stated by Anon. (2016) of which to achieve a good growth of banana plants, therefore before plantation it is necessary to ensure a crumbly soil when it is solid hard, to make drainage, and to make levels in slopes [1]. During plantation organic/compost fertilizers is needed as much as $15-20 \mathrm{~kg}$ for each ground hole for plantation [2]. Organic fertilizers that are added influences on a good production for both quantity and quality which makes the fruit tastier and has a higher nutritional value [3]. There are a few types of organic fertilizers found in the Angkah village that can be used such as: cow waste organic fertilizer, chicken waste organic fertilizer, pig waste organic fertilizer, goat organic waste fertilizer, and compost fertilizer from plant and other organic wastes. The utilization of organic fertilizers are not yet optimal, it is shown by much manure are scattered in the farmer's fields (near the animal housings) which may be drifted away during rainy season, especially for the pig waste. Organic fertilizers are very useful for plants because it could provide macro and micro nutrients, the media for root growth will be better, also it has the same characteristic as a soil such as; soil are more crumbly, can restrain moist longer, better soil aeration and drainage, and can reduce the drifting of soil during raining seasons [4].

Considering the reasons above therefore it is needed to conduct a research/evaluation of the use of various types of organic fertilizers that are found for banana plants so it could be useful to use manure waste and more sustaining a better environment. On the other hand, it is hoped that the production of the bananas could increase; therefore the fulfillment of fruits as food stocks can be optimal. By the increased production, it is hoped that farmers could earn more; therefore the prosperity of farmers can be elevated.

\section{RESEARCH METHOD}

The materials used in this research are seedlings of Green Thailand Bananas as much as 50 plants, cow waste organic fertilizer, chicken waste organic fertilizer, pig waste organic fertilizer, goat waste organic fertilizer, and compost fertilizer. The tools that are used in this research are plastic bags for soil and manure sampling, stationaries for observation and measurement in the field, a hoe, a sickle, knife/cutter, and other things. This Research is a field experiment which uses a factorial design with a fundamental Random Group Design (RGD). This research is commenced by achieving soil samples to analyze the nutrients. Soil sample that are taken in different pieces are achieved by the depths up to $30 \mathrm{~cm}$ in some of the research area and are then combined into one soil sample. The soil sample is dried by wind and then analyzed in the laboratory to find out the results of: $\mathrm{pH}$
$\left(\mathrm{H}_{2} \mathrm{O}\right)$, N-Total, $\mathrm{P}_{2} \mathrm{O}_{5}$ availability, $\mathrm{K}$-Total, salinity, and organic materials in the soil, as well as the texture of the soil. For organic fertilizer that is used, samples are also taken to analyze the composition values of: $\mathrm{pH}\left(\mathrm{H}_{2} \mathrm{O}\right), \mathrm{N}$ total, $\mathrm{P}_{2} \mathrm{O}_{5}$, and $\mathrm{K}_{2} \mathrm{O}$. Experiment with the organic waste fertilizers are treated by the followings:
1. $\mathrm{P} 0$
: Without fertilizers (controls)
2. PS
: Treatment with cow waste organic
3. $\mathrm{PA}$ fertilizer at $15 \mathrm{~kg}$ per plant
4. $\mathrm{PB}$
: Treatment with chicken waste organic fertilizer at $15 \mathrm{~kg}$ per plant
4. $\mathrm{PB}$
5. $\mathrm{PK}$
: Treatment with pig waste organic fertilizer at $15 \mathrm{~kg}$ per plant
6. Kom

\section{: Treatment with goat waste organic} fertilizer at $15 \mathrm{~kg}$ per plant
: Treatment with organic compost fertilizer at $15 \mathrm{~kg}$ per plant

All of the six treatments are each repeated 3 times, giving a total of 18 treatment areas. Observation of the research is started by looking at the vegetative development of the plant such as: height of the plant, amount and width of the leaves, flower timing (banana buds), and the weight of the fresh fruit. Results of the observation are analyzed statistically with differential Duncan test.

\section{RESULTS AND ANALYSIS}

The research results of influences of the types of organic fertilizers towards the growth and production of banana plantation are up until this paper was made has just been up to the observation aspect of the plantation. Observation of the vegetative growth was the increment of the amount of leaves and the height of the plant. The analysis result of the organic fertilizers and the soil of the research location can be found in Table 1 . On the table above shows that the composition or nutrients and organic soil in the research area were very low, therefore it is very much needed to be fertilized, especially with an organic fertilizer. The average growth of the plant can be seen in the observation result of the amount of leaves and the height of the banana plants found in Table 2 and Table 3.

Observation results of the amount of leaves and height of the banana plant was found that chicken waste organic fertilizer had the highest influences compared to the other organic fertilizer. There is a real influence of organic waste fertilizer towards the height of the banana plantation. This is caused by the composition of nutrient in the soil is low (table 1), and the composition of nitrogen, phosphate, and potassium elements in chicken waste fertilizer is the most highest compared to the other organic fertilizer. With the increase height of the plant and the amount if banana leaves is hoped to produced fruits which are much more abundance and faster. 
TABLE 1.

ANALYSIS RESULT OF ORGANIC FERTILIZER AND THE SOIL OF THE RESEARCH GROUNDS

\begin{tabular}{|c|c|c|c|c|c|c|c|}
\hline \multirow{2}{*}{ No. } & \multirow{2}{*}{ Item that are analyzed } & \multicolumn{6}{|c|}{ Result of Analysis } \\
\hline & & $\mathrm{pH}(1: 2,5)$ & C Organic $(\mathrm{mmhos} / \mathrm{cm})$ & $\mathrm{N}$ total $(\%)$ & $\mathrm{P}_{2} \mathrm{O}_{5}(\mathrm{ppm})$ & $\mathrm{K}_{2} \mathrm{O}(\mathrm{ppm})$ & Texture \\
\hline 1 & Cow waste & $7,1 \mathrm{~N}$ & $28,85 \mathrm{ST}$ & $0,63 \mathrm{~T}$ & $533,86 \mathrm{ST}$ & $550,80 \mathrm{ST}$ & \\
\hline 2 & Pig waste & $7,2 \mathrm{~N}$ & $20,27 \mathrm{ST}$ & $2,78 \mathrm{ST}$ & $410,27 \mathrm{ST}$ & $520,54 \mathrm{ST}$ & \\
\hline 3 & Chicken waste & $7,4 \mathrm{~N}$ & $24,04 \mathrm{ST}$ & $3,27 \mathrm{ST}$ & $977,61 \mathrm{ST}$ & $1074,35 \mathrm{ST}$ & \\
\hline 4 & Goat waste & $7,2 \mathrm{~N}$ & $23,80 \mathrm{ST}$ & $2,16 \mathrm{ST}$ & $816,53 \mathrm{ST}$ & $446,36 \mathrm{ST}$ & \\
\hline 5 & Compost & $6,8 \mathrm{~N}$ & $17,39 \mathrm{ST}$ & $0,53 \mathrm{~T}$ & $706,67 \mathrm{ST}$ & $589,51 \mathrm{ST}$ & \\
\hline 6 & Soil of research ground & $6,7 \mathrm{~N}$ & $1,72 \mathrm{R}$ & $0,18(\mathrm{R})$ & $0,27(\mathrm{SR})$ & 71,07 (SR) & Thick clay \\
\hline
\end{tabular}

Notes: $\mathrm{N}=$ Neutral; R = Low; SR = Very Low; T = High; $\mathrm{ST}=$ Very High

TABLE 2.

INFLUENCES OF TREATMENTS TOWARDS AMOUNT OF BANANA LEAVES

\begin{tabular}{ccccc}
\hline Treatment & \multicolumn{4}{c}{ Total Leaves (Sheets) On The Age Of The Plant } \\
\cline { 2 - 5 } & 1 Month & 2 Month & 3 Month & 4 Month \\
\hline P0. Controlled & 3.67 & 6 & 7.33 & $8,00 \mathrm{a}$ \\
PB. Pig waste & 4.33 & 6.67 & 7.67 & $7,67 \mathrm{a}$ \\
PA. Chicken waste & 5.67 & 7.33 & 8.67 & $8,67 \mathrm{a}$ \\
PK. Goat Waste & 5.33 & 7.33 & 8.67 & $8,67 \mathrm{a}$ \\
PS. Cow Waste & 5.00 & 6.67 & $8,67 \mathrm{a}$ \\
Kom. Compost & 4.67 & 6.67 & 7.67 & $8,33 \mathrm{a}$ \\
\hline
\end{tabular}

Note: The numbers that are followed by the letters in the same column shows there are differences with no real difference during the BNT test at $5 \%$.

TABLE 3.

INFLUENCES OF TREATMENT TOWARDS THE HEIGHT OF THE BANANA PLANTS

\begin{tabular}{|c|c|c|c|c|c|}
\hline \multirow{2}{*}{ Treatment } & \multicolumn{5}{|c|}{ Height of Banana Plant at Different Ages } \\
\hline & During plantation $(\mathrm{cm})$ & 1 Month $(\mathrm{cm})$ & 2 Month $(\mathrm{cm})$ & 3 Month $(\mathrm{cm})$ & 4 Month $(\mathrm{cm})$ \\
\hline P0. Controlled & 55.67 & 57.67 & 61.33 & 71.35 & 89,33 a \\
\hline PB. Pig waste & 51.33 & 53.33 & 57.33 & 84.67 & $103,33 \mathrm{~d}$ \\
\hline PA. Chicken waste & 53.33 & 57 & 66.67 & 92.33 & $116,33 \mathrm{e}$ \\
\hline PK. Goat Waste & 62 & 64.33 & 68.00 & 77.33 & $99,67 \mathrm{c}$ \\
\hline PS. Cow Waste & 61.67 & 64.33 & 68.33 & 76 & $98,00 \mathrm{c}$ \\
\hline Kom. Compost & 50.67 & 55.67 & 59.00 & 72.67 & $93,67 \mathrm{~b}$ \\
\hline
\end{tabular}

Note: The numbers that are followed by the letters in the same column shows there are differences with no real difference during the BNT test at $5 \%$.

\section{CONCLUSION}

The soil in the research location really needs to be fertilized especially with organic fertilizers. The chicken waste organic fertilizer has the best influences and was significant towards the growth (height) of the banana plant which was $115,3 \%$ from the time it was planted. While the controlled plant only grown by $88,33 \%$ by the time of plantation.

\section{ACKNOWLEDGMENT}

The researcher would like to thank the Dean of Agriculture Faculty and Head of LPPM of Udayana niversity for the help that is given so this service of research can be conducted. This research and services is funded by DIPA PNBP of Udayana University based on the legal letter For Research commencement Number: $1268 / \mathrm{UN} 14.1 .23$ /PL/2016, dated on the $21^{\text {st }}$ of September 2016.

\section{REFERENCES}

[1] Anonymous. 2016. Budidaya Pisang. Available from: http://www.produknaturalnusantara

[2] Bellamy, A. S. 2013. Banana Production Systems: Identification of Alterna-tive Systems for More Sustainable Production. Ambio. 42(3):334-343.

[3] Soeparjono, S. 2016. The Effect of Media Composition and Organic Fertilizer Concentration on the Growth and Yield of Red Ginger Rhizome (Zingiber officinale Rosc.). Agri-culture and Agricultural Science Procedia Vol. 9:450-455.

[4] Ssali, H., B. McIntyre, and C. Gold. 2003. Nutrient Cycling in Agroeco-systems 65:141. doi:10.1023/A: 1022184927506. 